\title{
Promising therapeutic agents for the treatment of Parkinson's disease
}

\section{Zsófia Majláth ${ }^{\mathrm{a}}$, Nóra Török ${ }^{\mathrm{a}}$, József Toldi ${ }^{\mathrm{b}}$ and László Vécsei ${ }^{\mathrm{a}, \mathrm{c}}$}

${ }^{\text {a }}$ Department of Neurology, Faculty of Medicine, University of Szeged, Szeged, Hungary

${ }^{\mathrm{b}}$ Department of Physiology, Anatomy and Neuroscience, University of Szeged, Szeged, Hungary

${ }^{\mathrm{c}}$ MTA-SZTE Neuroscience Research Group, Szeged, Hungary

Corresponding author:

László Vécsei MD, PhD, DSc

Department of Neurology, Faculty of Medicine, University of Szeged, 6 Semmelweis u., H-6725 Szeged,

Hungary

Tel: +3662545351

Fax: +3662545597

email: vecsei.laszlo@med.u-szeged.hu

\begin{abstract}
Introduction: Therapeutic management of Parkinson's disease is not yet fully resolved, with motor fluctuations and levodopa-induced dyskinesia representing special therapeutic challanges. Furthermore, no disease-modifying therapies are currently available.

Areas covered: The review focuses on promising novel therapies that are at present under investigation in Phase I and Phase II trials. Special emphasis will be placed on gene therapies, adenosine $\mathrm{A}_{2 \mathrm{~A}}$ antagonists, metabotropic glutamate receptor 5 antagonists, and calcium channel blockers.

Expert opinion: Gene therapies represent a promising field in the therapeutic palette. In order to mitigate the side effects of this therapy, the developments are focusing on the applied vectors.
\end{abstract}


Isradipine has been suggested to have neuroprotective properties; however, clinical evidence is still eagerly awaited. Though the development of metabotropic glutamate receptor 5 antagonist mavoglurant has recently been discontinued due to moderated efficacy, investigations on dipraglurant are still ongoing. Adenosine $\mathrm{A}_{2 \mathrm{~A}}$ antagonists appear to be promising agents in the management of motor complications in advanced stages of Parkinson's disease.

Keywords: Parkinson's disease, levodopa-induced dyskinesia, adenosine $\mathrm{A}_{2 \mathrm{~A}}$ antagonist, gene therapy, metabotropic glutamate receptors

\section{Introduction}

Parkinson's disease (PD) represent the second most prevalent chronic progressive neurodegenerative disease among the elderly ${ }^{1}$. Its neuropathological hallmarks include the preferential degeneration of dopaminergic neurons in the substantia nigra pars compacta (SNPc) and the presence of intraneuronal inclusions consisting primarily of a-synuclein, the Lewy bodies. As the disease affects millions of families worldwide and causes serious problem in the aging societies, its social significance is remarkable. A meta-analysis of a worldwide dataset revealed an increasing prevalence of PD with age: 41/100,000 between 40 and 49 years; 428/100,000 between 60 and 69 years; and 1903/100,000 above 80 years of $\operatorname{age}^{2}$.

Protein aggregation, mitochondrial disturbances, oxidative stress, glutamate excitotoxicity, alterations of the tryptophan metabolism, immunological mechanisms, and genetic predisposition are all proposed to play significant roles in the etiopathology of the disease $\mathrm{e}^{\frac{3-13}{3}}$.

The diagnosis is based on the identification of the classical motor symptoms (tremor, rigidity, hypokinesia and difficulty walking). In addition to these, however, non-motor symptoms are also characteristic of the disorder (i.e., dementia, depression, sleep disorder, as well as emotional, cognitive, and behavioral problems) $\stackrel{14}{\text {. }}$

The introduction of long-term dopamine (DA) replacement therapy with 3,4-dihydroxyL-phenylalanine (L-DOPA), the precursor of DA, represents a milestone in the treatment of PD. However, the drug can evoke side effects, which include L-DOPAinduced dyskinesia (LID) and non-motor fluctuations with cognitive dysfunction and 
neuropsychiatric symptoms (i.e., compulsive behaviors and impulse control disorders)

16. Therefore, the benefits of L-DOPA treatment may be overshadowed by these troublesome side effects as well as by the appearence of symptoms that are not responsive to dopaminergic treatments (i.e., autonomic symptoms, gait and balance problems, and cognitive impairment $)^{17}$. These issues together with the lack of neuroprotective agents available represent the driving force behind the search for new therapeutic possibilities. In the last decade, several novel drugs have been developed and tested in PD, however, so far only a small number of them have reached the market $\underline{18,} \underline{19}$.

In this review, we focused on summarizing the results of recent phase I and II clinical trials with new potential therapeutic agents in PD.

\section{Novel therapeutic possibilities in PD}

\subsection{Gene therapy}

In the past decade, a new player appeared in the therapeutic palette, aiming to fill the above mentioned therapeutic gaps, that is gene therapy. Gene therapy refers to the application of a gene or genetic material (including DNA and RNA) as an agent to modulate cellular/biological functions with the aim of treating a disease ${ }^{17}$.

Clinical gene therapy approaches can be divided into two categories (Figure 1.). The first option is ex vivo gene therapy, in which the patients recieve genetically modified cells that express a desired protein or proteins. The second possibility is in vivo gene therapy, in which the genetic information is directly inserted into the patient's own cells. To date, all human clinical trials applied the in vivo method by the use of viral vectors; however, ex vivo gene therapeutic strategies may as well play a role in the treatment of PD in the future ${ }^{20-22}$. Of note, specific risks exist in association with the use of gene therapeutic approaches. Indeed, the uncontrolled overproduction of the expressed protein can cause undesirable effects. Appropriate selection of the gene promoter, a region that controls the gene expression, might be a solution for this probem $^{23}$.

Figure 1. 
A number of risk factors inheritedly exist as regards the in vivo gene therapy as well, including the induction of insertional mutagenesis as well as autoimmune and inflammatory responses in the patients. In the case of insertion mutagenesis, the introduced gene integrates into the host genome at a site that promotes oncogenesis. The use of viral vectors can keep the risks of insertion mutagenesis at a low level. Further potential risks of harm include the autoimmune and inflammatory responses of the body of the patients. This risk can be also mitigated by the use of certain viral vectors and by a careful control of immune and inflamatory responses during the therapy.

Viral and non-viral vectors are both available for the delivery of genetic material into the host cells. Non-viral techniques are mainly tested in preclinical models; therefore, in this present work, the review of these techniques is limited to short descriptions. These methods include electroporation, gene gun, intranasal injection of the genetic material, and liposomes coated with polyethyleneglycol (PEG). The electroporation techniques enhance the permeability of the membranes after the injection of the genetic material by applying controlled electric fields. The gene gun method represents a direct gene delivery into tissues or cells by injecting gold particles coated with DNA, which can penetrate into the nucleus. The other two approches allow an easier access to the central nervous system (CNS), as they solve the problem of getting across the blood-brain barrier (BBB). The first solution is the direct intranasal injection of the genetic material, whereas the second option is transferring the genetic material via liposomes (coated with PEG), which are stable in blood and, after modifications, they can be actively transported into the CNS.

The first vectors used for gene therapy were of adenoviral and herpes simplex viral types; however, they were replaced by two vectors that are less toxic and less prone to produce immune response. At present, the most widely applied vectors are the lentiviral and the adenoassociated viral (AAV) vectors. In case of $\mathrm{AAV}$, the majority of the virus genome is removed, which results in a decreased risks of secondary immune reactions and insertion mutagenesis. Because the majority of the virus genome is removed, the viral genome remains episomic and is not integrated into the host genome, thereby reducing the risk of insertional mutagenesis. Due to these advantages of the AAV vectors, this is the most commonly used type of vectors for gene therapy. Nonetheless, it has a main limitation, which is the restriction of the size of the delivered gene constructs. On the other hand, lentiviral vectors can deliver larger gene constructs. Of note, these constructs integrate into the host genome, which on the one hand may evoke insertional mutagenesis, whereas on the other hand, this approach enables longer 
gene expression as a benefit of the integration. Nevertheless, it should be noted that the target neurons are mainly in their postmitotic stage, which may limit the risk of insertional mutagenesis. One of the main problems to be solved as regards viral gene therapy is the penetration of the agents across the BBB. Notably, neither of these two viruses can pass through the BBB; therefore, this form of treatment requires craniotomy.

The aims of gene therapy in PD are to increase the extent of DA production or the number dopaminergic nerve terminals. Altogether eight PD gene therapies have so far been conducted in phase I or phase II clinical trials (Table 1.). All of them used AAV or lentiviral vectors.

\subsubsection{AAV2-GADAdeno-associated viral type 2- glutamic acid decarboxylase (AAV2-} GAD)

The first human in vivo gene therapy study with the aim of treating neurodegenerative disorders was a safety and tolerability study with the AAV2-GAD construct in PD 24 .

The used gene was the glutamic acid decarboxylase (GAD), which encodes the rate-limiting enzyme for the synthesis of gamma-aminobutyric acid (GABA), the major inhibitory neurotransmitter within the brain. Earlier studies revealed that the CSF level of GABA is significantly decreased in $\mathrm{PD}^{25}$ and that GABAergic drugs injected into the region of the subthalamic nucleus (STN) could attenuate the disease symptoms ${ }^{\frac{26}{}}$. In PD, the activity of the STN is increased, mainly due to a decrease in GABAergic inhibition from the globus pallidus $^{27-29}$. In line with these, encouraging results emerged from preclinical experiments on rats ${ }^{\underline{30}}$ and macaques $\underline{\underline{31}}$ with AAV2-GAD therapy.

In a human clinical trial, 11 male and 1 female PD patients between 25 and 70 years of age and with a Hoehn and Yahr stage of 3 or greater were enrolled, all of them presenting with intolerable motor complications due to L-DOPA. Four patients received low-dose, four received medium-dose, and four received high-dose AAV2-GAD injections, which were injected unilaterally into the subthalamic nucleus (STN) region of the clinically less affected side. Each patients underwent surgery, and there were no dropouts or patients lost. No treatment-related adverse events or immune responses were reported during the one year of follow-up. Significant improvements were measured in the motor Unified Parkinson's Disease Rating Scale (UPDRS) scores after 3 months, predominantly on the side of the body contralateral to the surgery, and this effect persisted for the duration of the trial. 18F- 
fluorodeoxyglucose positron emission tomography (18F-FDG-PET) was used to assess the changes in regional metabolism and network activity after the treatment. The above results were associated with increases in metabolism in the premotor cortex of the operated hemispheres, suggesting that the therapy changed the activity of the motor cortico-striatopallido-thalamo-cortical circuit, which ameliorated the motor function-as well as preserved the cognitive functioning in these patients 32 . Contrary the activity of the cognition-related network did not change after gene transfer, which suggests that the modulation of abnormal network activity underlies the clinical benefit of the AAV-GAD gene therapy in $\mathrm{PD}^{32}$.

After this successful Phase I study, a double-blind, Phase II, randomised-controlled trial was conducted in seven centers in the USA, which was a bilateral delivery trial with AAV2$\mathrm{GAD}^{\underline{33}}$. All patients enrolled had a progressive, L-DOPA-responsive, advanced PD, with a UPDRS motor score of 25 or above, and with an age betwen 30 and 75 years. The utilized dose was the highest applied in the Phase I trial $\left(1 * 10^{12} \mathrm{vg} / \mathrm{ml}\right) .23$ patients were randomly selected to sham surgery and 22 to AAV2-GAD therapy; out of these, eventually 21 and 16 patients were examined, respectively. The sham group received bilateral intradural injection of sterile saline. The endpoint of the trial was at 6 months after surgery. Significant difference was observable in the UPDRS scores, with 8.1$(23 \%)$ and 4.7-point (13\%) decreases in the AAV2-GAD and the sham group, respectively. The AAV2-GAD group achieved a significantly greater improvement from baseline in UPDRS scores as compared with the sham group the 6-mont duration of the study. The reported mild and moderate adverse events were probably related to surgery, presenting in headache and nausea.

These results support the rationale for further development of bilateral injection therapy with AAV2-GAD into the subthalamic nucleus for PD, and suggest promising opportunities for gene therapy in other neurological disorders.

It could be noticed from the above results that not only the treatment group but also the shamtreated group achieved a certain extent of amelioration. This placebo or sham effect represents a major obstacle in the development of therapies in PD. A recent study suggest the use of individualized subject selection based on a predetermined network criterion, which may limit the need for sham interventions in future clinical trials ${ }^{34}$.

\subsubsection{AAV2-Glial-derived Neurotrophic Factor}


Gene therapy can be applied to halt the disease progression and to restore neuronal function. To achieve these goals, neurotrophic factors can be used to promote normal cell function and to enhance the survival of damaged nigral dopaminergic neurons.

The most extensively studied neurotrophic factor in PD is the glial cell line-derived neurotrophic factor (GDNF). Its safety and efficacy have been demonstared at the preclinical level in PD animal model studies, in which direct injection of GDNF was proven to ameliorate nigrostriatal dopaminergic cell death and to promote dopaminergic axonal sprouting ${ }^{35-38}$. Moreover, in primate models of PD, findings on the effects of GDNF treatment with the use of different viral vectors suggested that this form of therapy may mediate plasticity in the DA-depleted brain and ameliorate the lesion-induced behavioral deficits $\underline{39}, \underline{40}$.

Human ICV administration therapeutical studies provided rather promising results ${ }^{41}, \underline{42}$, which could further facilitate the initiation of viral vector-mediated delivery of GDNF genes in the clinical practice ${ }^{43}$.

The most extensively examined GDNF family member, Neurturin (NTN) (CERE-120), showed efficacy and safety both in 1-methyl-4-phenyl-1,2,3,6-tetrahydropyridine (MPTP)induced primate and 6-hydroxydopamine (6-OHDA)-induced rodent models of the disease ${ }^{44}$.

Twelve PD patients were treated in a Phase I trial with bilateral intraputaminal injection of NTN with 2 dose levels without serious adverse events ${ }^{45}$. The therapy was safe and welltolerated, and after 1 year, significant clinical improvement (36\%) was reached in OFFmedication motor UPDRS scores. At the same time, the 18F Fluorodopa PET imaging did not indicate significant increases in the number of dopaminergic nerve terminals.

In 2010, 58 PD patients were enrolled in a randomized, double-blind, sham surgery-controlled clinical trial ${ }^{46}$. Unfortunately, there were serious adverse events in 13 of 38 patients from the treated group and 4 of 20 from the sham surgery cohort. Three patients from the first (one glioblastoma, one oesophageal adenocarcinoma and one adenocarcinoma of the prostate) and two from the second (parotid gland tumor, apocrine gland adenocarcinoma) group developed tumors. The quantitatative PCR assays were negative for AAV2-neurturin in each occasion. In case of the glioblastoma the deeper investigation revealed that it had been present on MRI before the study entry. For these reasons the tumours were not thought to be related to the AAV2-neurturin treatment, albeit this possibility cannot be completely foreclosed. Two patients from the treated group died (one myocardial infarction 
at 47 days and one pulmonary embolism at 91 days postoperatively), but these deaths were not judged to be related to the treatment ${ }^{46}$.

Moreover, The patients who received NTN treatment did not reach significant improvement in OFF-state motor UPDRS scores at the end of the first year. However, the study raised the possibility that benefit might be achieved by additional targeting of the substantia nigra and by the use of longer term follow-up periods in future studies.

In a two-year safety trial of bilateral therapy of CERE-120 injected into the SN and putamen suggested that the procedures were safe (Class IV evidence) and well tolerated, with no serious adverse events reported ${ }^{47}$.

Based on these observations, a Phase IIb, double-blind, sham surgery-controlled trial investigated the efficacy of combined intraputaminal and intranigral gene delivery of CERE120 in PD patients ${ }^{17}$. Even though this trial could not confirm the efficacy of the treatment at the primary endpoint, there were significant improvements achieved in certain secondary endpoints. Nevertheless, the therapy was safe and well tolerated.

A recent published results failed to show better efficacy compare to sham surgery in a doubleblind, randomized AAV2-Neururin treatment bilaterally in the substantia nigra and the putamen (NTC00985517) ${ }^{48}$. There were no significant difference between the two groups in the primary and most in the secondary endpoints. No clinically relevant adverse events occurred to the treatment; only two patients had cerebral hemorrhages with transient symptoms. The therapy was safe and well-tolerated.

Post-mortem assessment of four patients after putaminal neurturin treatment revealed modest improvement in the patients's brain even four year after the therapy $\underline{49}$. It was an evidence of the long-term, stable and persistently targeted gene-transfer-mediated neutrophic factor expression, but these neurons represented a very small proportion of the total neuronal population. These results may help to design the treatment protocols in the future therapies.

A new study is currently recruiting its participants for an open-label dose-escalation study of AAV2-GDNF delivery in advanced PD patients to analyze the safety, tolerability, and efficacy of bilateral treatment into the putamen in 4 doses (NCT01621581).

The summary of recent studies suggests that this therapeutic approach may only be effective in relatively mild PD, which can be an explanation for the negative results of the clinical trials to date ${ }^{17}, \underline{50}$. 


\subsubsection{AAV2-AADC}

Another gene therapeutical opportunity in PD is to improve the efficiency of L-DOPA conversion to DA. The aromatic L-amino acid decarboxylase (AADC) gene encodes an enzyme that transforms both endogenous and pharmacologically administered L-DOPA to DA, which suggests a promising opportunity. In advanced PD, the activity of AADC is reduced due to the loss of nigrostriatal neurons, thereby reducing the level of endogenous DA. Due to reduced DA levels, the patients require higher doses of L-DOPA ${ }^{44}$. In vivo gene therapy by the use of AAV2-AADC construct can enhance DA synthesis and may ameliorate the efficacy of the applied L-DOPA treatment. The terapeutic benefit might be the reduction of the utilized dose of L-DOPA, which could result in an alleviation in the associated side effects.

Earlier preclinical studies with primate models of PD resulted in robust gene expression changes lasting for more than seven years $\frac{51}{1}, \underline{52}$; therefore, lower doses of L-DOPA were sufficient and behavioral improvement could be reached without side effects typically associated with higher doses of L-DOPA.

Five moderate-to-advanced PD patients were enrolled in the first human Phase I safety trial with bilateral injection of a low dose of AAV2-AADC vector into the putamen ${ }^{53}$. The results showed a modest improvement; nevertheless, the absence of control group and the nonblinded analysis made the interpretation difficult. These initial data demonstrated the safety and tolerability of the therapy at low-dose, and prompted to try higher doses in future trials to come.

In the next trial, 10 patients with moderately advanced PD received bilateral intraputaminal treatment ${ }^{54}$. Five of them received low-dose and five of them received high-dose therapy, and the standardized clinical rating scales were used to measure the clinical state at baseline and at 6 months. The therapy was well tolerated in these cohorts as well, only the surgical intervention showed possible association with increased risks of intracranial hemorrhage and headache. Asymptomatic hemorrhage (at 2 subjects), small subdural/subarachnoid hemorrhage (at one patient), intracerebral hemorrhage associated with venous infarct (at one subject) and symptomatic hemorrhagic infarct had occurred. The hemorrhages happened along the trajectory of the catheter, but far from the place of infusion, presumably there were side effects of the surgical procedure. The most common 
adverse event were the self-limited headache and discomfort at the operation site, but they were short-lived. No related adverse events occurred along the AAV2-AADC

therapy. The measured total and motor rating scales improved in both treatment groups. The 6-month ${ }^{18} \mathrm{~F}$ fluoro-L-m-tyrosine (FMT) PET results showed greater improvement in the higher-dose as compared with the lower-dose cohort ( $75 \%$ vs 30\%). The necessary amount of dopaminergic medication was reduced in 8 patients ( 5 from the high-dose and 3 from the low-dose group). These results provided class IV evidence for the improvement of the mean scores in the UPDRS by approximately $30 \%$ in both the ON and OFF states.

A subsequent study aimed to retrospectively analyze the magnetic resonance imaging (MRI) and PET data from theabove mentioned Phase I trial. Morover, the study correlated the data with similar non-human primate dataset to improve future PD gene therapy trials in preparation for the initiation of the Phase II trial ${ }^{\underline{55}}$. Ten PD patients treated with bilateral MRI-guided putaminal infusions of AAV2-AADC were enrolled and three normal adult non-human primates received similar infusions into their thalamus. Based on the joint alanysis of the MRI, PET, and AADC immunohistochemistry results, the authors presented recommendations for future protocols with the use of T2-weighted MRI, as this modality appeared to allow visualization of a significant part of the distribution volume of the AADC therapy.

\subsubsection{ProSavin $\underline{\circledR}$}

ProSavin $\stackrel{[}{-}$ therapy includes 3 different genes that are involved in the production of endogenous DA synthesis. Tyrosine hydroxylase (TH) and guanosine triphosphate cyclohydrolase $(\mathrm{GCH})$ are responsible for catalyzing the conversion of dietary tyrosine to LDOPA, which can then be further metabolized to DA via AADC. The aim of this approach is not only to increase the DA level in the striatum (via increased AADC activity), but also to further increase the availability of endogenous L-DOPA.

Preclinical studies in 6-OHDA-induced rodent and MPTP-induced primate PD models provided promising results with the intrastriatal transduction of three AAV vectors, which separately carried the three genes ${ }^{17}$. These vectors were able to increase dopamine concentrations, so later a three gened lentivirus vector was developed to transduce genes for all three enzymes [Lenti-TH-AADC-GCH (ProSavin $@$ )]. This was able to increase extracellular striatal DA concentrations in animal models of $\mathrm{PD}^{\underline{56}}$. The advantage of this 
technique is that it may be suitable for providing long-term gene expression and thereby less pulsatile DA delivery in the striatum. This benefit could presumably reduce the risk of LDOPA-associated side effects (i.e. dyskinesia and hallucination). The first results in an MPTP macaque model treated with striatal injection of the tricinstronic lentiviral vector demonstrated that this treatment was safe and effective without evoking dyskinesias ${ }^{\underline{57}}$.

The first Phase I/II open-label trial with a 12-month follow-up demonstrated the safety and efficacy of ProSavin $\underline{\circledR}$ after bilateral injection into the putamen ${ }^{56}$. Fifteen patients received three doses of ProSavin $\underline{\mathbb{}}$, three of them received low-dose $\left(1.9 * 10^{7}\right.$ transducing units (TU)), six of them received mid-dose $\left(4.0^{*} 10^{7} \mathrm{TU}\right)$, and six of them received high-dose $\left(1 * 10^{8} \mathrm{TU}\right)$ treatment. After the first year of follow-up, 54 mild or moderate adverse events were reported, and no serious adverse events occured. Significant improvement could be detected in mean UPDRS motor scores OFF medication compared with baseline in every patients at 6 months and after one year $(\mathrm{NCT} 00627588)^{\frac{56}{6}}$. This safety, tolerability and efficacy trial has been prolonged for 10 years in order to provide further data about ProSavin $\underline{\AA}$ therapy (NCT01856439). Furthermore, preparations have been started to optimize the effective drug dose for a randomized, placebo-controlled human clinical trial ${ }^{17}$.

Summarizing these results, the above clinical trials have shown that these therapies are generally safe and well tolerated, suggesting that this method could be an applicable treatment for PD in the near future.

\subsection{Other therapeutic possibilities:}

\subsubsection{Metabotropic glutamate receptor 5 antagonists}

The development of LID, an important complication of L-DOPA substitution, has a severe impact on the quality of life of PD patients. The pathomechanism of LID has been associated with alterations of both dopaminergic and glutamatergic neurotransmission. Metabotropic and ionotropic glutamate receptor antagonists have been suggested to be able to alleviate LID based on the findings of animal models ${ }^{\underline{58}}$. Mavoglurant (AFQ056) is a selective metabotropic glutamate receptor 5 antagonist, the beneficial effects of which on LID were first shown in primates $^{59}$. Two randomized, double-blind, placebo-controlled Phase II studies evaluated the efficacy of mavoglurant in PD patients with moderate-to-severe LID. The two studies assessed LID by the use of two different scales: the Lang-Fahn Activities of Daily Living 
Dyskinesia Scale and the modified Abnormal Involuntary Movement Scale. Although these studies involved only 29 patients, both of them clearly confirmed the efficacy of mavoglurant. Dyskinesia significantly improved without any influence on the antiparkinsonian effect of L$\mathrm{DOPA}^{60}$. Another clinical trial conducted by Stocchi et al. also confirmed its efficacy and safety in 2013(Nincs az endnote-ban ilyen szerzö, sőt utána is két cikket említesz, de csak egy hivatkozás van a mondat végén); however, two following clinical trials (NCT01385592 and NCT01491529) have failed to prove its efficacy and the investigations of mavolgurant have therefore been discontinued ${ }^{61}$.

Dipraglurant (ADX48621), another metabotropic glutamate 5 receptor antagnoist, has so far been investigated in a Phase IIa study. The primary outcomes were safety and tolerability, and the study involved PD patients with moderate-to-severe LID. The results showed a moderate efficacy in reducing LID, and the drug was generally well tolerated. The main adverse events reported were nausea, dizziness, and dyskinesia. The company has already announced the initiation of a Phase II trial, and a PET-imaging study is also currently ongoing to assess metabotropic glutamate receptor 5 occupancy of dipraglurant $\underline{62}, \underline{63}$.

\subsubsection{Calcium channel blockers}

Isradipine is a member of dihydropiridyne calcium channel blockers and is an approved drug for treating hypertension. However, it has recently been suggested to have a diseasemodifying potential in PD patients. The first data suggesting its protective role came from mouse models of $\mathrm{PD}^{64}, \underline{65}$. Later, epidemiological studies also indicated that the use of calcium channel blockers as antihypertensive therapy was associated with a reduced risk of developing $\mathrm{PD}^{66}$, 67 . The possible background and the importance of Cav1.3-containing L-type calcium channels in the regulation of DA receptor responses in the substantia nigra have been described only recently $\underline{68, \underline{69}}$.

A pilot study evaluated the safety and tolerability of isradipine in PD patients in 2010, which confirmed that isradipine up to $10 \mathrm{mg}$ was was well tolerated and caused only minor side effects, the most frequent ones being dizziness and leg edema ${ }^{70}$. Furthermore, in this study, isradipine had no effect on blood pressure or motor function of PD patients. These results have been confirmed by a Phase II trial, which established the maximum tolerated dose of isradipine to be $10 \mathrm{mg}^{71}$. Whilst the current data did not confirm any immediate symptomatic benefit in PD patients, based on the promising preclinical results and the good tolerability, 
isradipine warrants further investigation to assess its possible neuroprotective capacity. A Phase III study is currently ongoing to assess the efficacy of isradipine in PD.

\subsubsection{Adenosine A2A receptor antagonists}

Adenosine $\mathrm{A}_{2 \mathrm{~A}}$ receptors have been implicated in the pathomechanism of $\mathrm{PD}$, as they may take part in the modulation of glutamatergic and GABA-ergic neurotransmission and may also influence striatal DA receptors. This mode of action may influence the activation of the indirect striatopallidal pathway. Adenosine $\mathrm{A}_{2 \mathrm{~A}}$ antagonists (Figure 2.). have been tested as an early monotherapy for previously untreated PD patients, but they may also hold promise for PD patients with motor fluctuations or dyskinesia ${ }^{72}$. Several $A_{2 \mathrm{~A}}$ antagonists have already been developed, such as istradefylline, tozadenant, vipadenant and preladenant.

Figure 2.

Istradefylline is the first $\mathrm{A}_{2 \mathrm{~A}}$ antagonist that has been approved for marketing in Japan, although in the United States, the Food and Drug Administration (FDA) rejected its approval. The drug has been tested both as a monotherapy and in combination with L-DOPA. As a monotherapy, istradefylline did not improve motor symptoms of PD patients $\frac{73}{2}, \frac{74}{}$. However, as an adjunctive therapy to L-DOPA, istradefylline produced more promising results. Several studies revealed an improvement in UPDRS motor scores; however, some of them did not prove any motor improvement $\underline{73}, \underline{75}, \underline{76}$. On the other hand, a more consistent finding was the reduction of the OFF-time and the prolonged effect of L-DOPA $\stackrel{73}{\text {, }}$, 7 ,7-79. Istradefylline was generally well tolerated, the most commonly reported adverse events were nausea, dizziness, and the prolongation of dyskinesia during the ON-time. Interestingly, the severity of dyskinesia did not worsen, only its duration increased, which was mostly considered by the patients to be well tolerable. As the FDA did not approve the use of istradefylline and considered the available evidence to be insufficient, further investigations are on their way to assess the efficacy of this novel drug.

Tozadenant is another very promising $\mathrm{A}_{2 \mathrm{~A}}$ receptor antagonist, which has already successfully completed two Phase II trials. In the first trial, 20 and $6 \mathrm{mg}$ daily doses of tozadenant were assessed, and the drug was confirmed to improve UPRDS motors scores by $20 \%$. The 
beneficial effects were particularly pronounced in relation to the amelioration of bradykinesia $^{80}$. The effect was dose-dependent. In the other Phase II trial, four doses of tozadenant were investigated, ranging between $60 \mathrm{mg}$ and $240 \mathrm{mg}$. This study was of 12 weeks duration and all doses were administered in combination with L-DOPA. The results reached statistical significance in all outcome measures: reduction of OFF-time, increase of ON-time, and improvements in both motor and non-motor UPDRS scores $\frac{81}{}$. The reported adverse events were very similar to those of istradefylline: dizziness, nausea, dyskinesia, and insomnia.

Preladenant and vipadenant displayed promising efficacy in Phase II trials; however, the research on both drugs has been discontinued. Preladenant failed in Phase III trials, while vipadenant was associated with safety issues, and therefore the investigations now focus on a next-generation compound, V8144롤.

\section{Conclusion}

The first evidence from the PD gene therapy trials showed that these approaches are safe and well tolerated, but none of the studies have indicated sufficiently robust clinical efficacy. The most important advantage of these studies that they contribute to the solution of major safety hurdles that previously suppressed CNS-related gene therapy. The main remainig tasks include the development of more predictive animal models, optimization of clinical trial design and patient selection, development of better delivery approaches and finally the establishment of the appropriate dose. Metabotropic glutamate receptor 5 antagonists are investigated for the therapy of LID, so far, only limited results are available. The calcium channel blocker isradipine has been suggested to be neuroprotective, currently only the safety is confirmed in $\mathrm{PD}$ patients. Adenosin $\mathrm{A}_{2 \mathrm{~A}}$ antagonists show promise for the management of motor complications in advanced PD patients.

\section{Expert opinion}

\section{4.}

Therapeutic management of PD patients often represents a challenge for neurologists. While the gold standard remains L-DOPA substitution, long-term therapy may induce motor complications such as dyskinesia, and the non-physiological stimulation of DA receptors may 
also result in motor fluctuations. The therapy of these complications, as well as that of nonmotor symptoms remain to be solved. Another important therapeutic gap is the lack of disease-modifying agents, as currently no proved neuroprotective drug is available. A number of novel approaches exist aiming to solve the problem of this terapeutic gap. Over the last 10 years, several new techniques appeared in the palette of clinical trials. One of them was the gene therapy. Like other therapetic modalities, gene therapy approaches have both advantages and disadvantages. The most important advantages include that these approaches may exert both symptomatic and disease-modifying effects, and that, by the application of genomeintegrating lentiviral vectors, long-term gene expression can be reached. The symptomatic approach have concentrated on increasing of the dopamine production (AADC, TH, GCH)/enhancing the efficiency of the levodopa conversion to dopamine (AADC) and normalizing the basal ganglia circuitry (GAD) by modulation of the neuronal phenotype $\underline{17}, \underline{83}$. The main disadvantages of all therapies directed at replacing dopamine are unlikely to solve the burden of non-dopaminergic problems in PD. The disease modifying approach have focused on halt the disease progression, restore neuronal function and increasing dopaminerg nerve terminals (GDNF, Neurturin) ${ }^{17}$. However, the use of this therapy carries several inherited risks and side effects. Some of these side effects are attributed to craniotomy such as headache and hemorrhage. No serious adverse events related to the virus or the carried gene(s) occurred in the clinical trials so far. Indeed, $\underline{T}$ the currently applied viral vectors are unable to penetrate the $\mathrm{BBB}$; therefore, effort needs to be put in the development of gene therapeutic approaches that will not require surgery in the future. Immunogenicity and carcinogenicity are also among the main risks of the therapy; however, certain approaches already exist to decrease these risks. Other disadvantages of viral vectors include their poor specificity to the target cells, the limited size of the genes that can be transduced, and the high expenses of the approach. Therefore, other approaches (non-viral vectors, nanocarriers etc.) may be potential alternatives to viral vectors to reach better efficiency in gene therapy ${ }^{84}$. Summarizing the above detailed results, gene therapy that targets the striatum, STN, and substantia nigra can be safe and well tolerated in PD patients; however, significant challenges remains to be solved in the future. The most important questions are how we can control and modulate gene expression, and how to determine the optimal target, dose, and patient population. The answers to these questions require further clinical investigations.

The calcium channel inhibitor isradipine has been suggested to have neuroprotective properties, but strong clinical evidence is still eagerly awaited. Clinical studies suggest that 
isradipine is well tolerated; however, the currently available data is limited, and larger cohorts of patient are needed to draw conclusions. The risk of orthostatic hypotension, which is a frequent symptom in PD patients, is an important issue; however, only patients in very early stages of PD have so far been involved in the trials, which necessitates isradipine be tested in advanced stages as well to permit conclusions on this potential side effect. Nevertheless, isradipine seems to be generally well tolerated, hence efficacy studies are awaited to prove its disease-modifying property.

After the first promising results, the metabotropic glutamate receptor 5 antagonist mavoglurant failed to prove efficacy in the treatment of LID. However, clinical trials confirmed that targeting metabotropic glutamate receptors 5 may still be a rational approach to manage LID. Dipraglurant is currently investigated in clinical trials, but the first data were reassuring. Improtantly, antagonists of metabotropic glutamate receptor 5 were well tolerated and safe; therefore, future investigations are definitely warranted.

Adenosine $\mathrm{A}_{2 \mathrm{~A}}$ antagonists are promising novel candidates for drug development, especially for the management of motor complications in advanced stages of PD. Istradefylline is already marketed in Japan; however, the FDA considered the available evidence inconclusive for approval. While the prolongation of the ON-time seems to be confirmed, the different trials yielded mixed results as concerns the motor symptoms. Another important aspect is the presence of dyskinesia, as it has been reported to be prolonged by istradefylline. Though most patients considered the dyskinesia non-troublesome, further investigations are justified to assess the global effect of istradefylline on motor functions and the quality of life of PD patients. Tozadenant have so far produced more conclusive results, and importantly, it did not worsen dyskinesia in the ON-time. This drug was also able to improve non-motor UPDRS scores. The currently available therapies are often unable to manage motor complications in advanced PD patients; therefore, $\mathrm{A}_{2 \mathrm{~A}}$ antagonists are promising candidates and are likely to reach the market in the next decade.

\section{Conflict of interest}

The authours declare that they have no conflicts of interest.

\section{Acknowledgments}


This work was supported by the project TÁMOP-4.2.6.3.1., by the Hungarian Brain Research Program (NAP, Grant No. KTIA_13_NAP-A-III/9. and KTIA_13_NAP-A-II/17.) and by the MTA-SZTE Neuroscience Research Group of the Hungarian Academy of Sciences and the University of Szeged.

\section{For the linguistic corrections we are greatful to David Durham and Levente Szalárdy.}

\section{References}

1. Schrag A, Horsfall L, Walters K, Noyce A, Petersen I. Prediagnostic presentations of Parkinson's disease in primary care: a case-control study. Lancet Neurol 2015 Jan;14(1):57-64.

2. Pringsheim T, Jette N, Frolkis A, Steeves TD. The prevalence of Parkinson's disease: a systematic review and meta-analysis. Mov Disord 2014 Nov;29(13):1583-90.

3. Klivenyi P, Kekesi KA, Hartai Z, Juhasz G, Vecsei L. Effects of mitochondrial toxins on the brain amino acid concentrations. Neurochem Res 2005 Nov;30(11):1421-7.

4. Zadori D, Szalardy L, Toldi J, Fulop F, Klivenyi P, Vecsei L. Some molecular mechanisms of dopaminergic and glutamatergic dysfunctioning in Parkinson's disease. J Neural Transm 2013 Apr;120(4):673-81.

5. Greenamyre JT, MacKenzie G, Peng TI, Stephans SE. Mitochondrial dysfunction in Parkinson's disease. Biochem Soc Symp 1999;66:85-97.

6. Oczkowska A, Kozubski W, Dorszewska J. [Alpha-synuclein in Parkinson's disease]. Przegl Lek 2014;71(1):26-32.

7. Caudle WM, Zhang J. Glutamate, excitotoxicity, and programmed cell death in Parkinson disease. Exp Neurol 2009 Dec;220(2):230-3.

8. Spatola M, Wider C. Genetics of Parkinson's disease: the yield. Parkinsonism Relat Disord 2014 Jan;20 Suppl 1:S35-8.

9. Blandini F. An update on the potential role of excitotoxicity in the pathogenesis of Parkinson's disease. Funct Neurol 2010 Apr-Jun;25(2):65-71.

10. Reale $M$, larlori C, Thomas A, Gambi D, Perfetti B, Di Nicola $M$, et al. Peripheral cytokines profile in Parkinson's disease. Brain Behav Immun 2009 Jan;23(1):55-63.

11. Jenner P. Oxidative stress in Parkinson's disease. Ann Neurol 2003;53 Suppl 3:S26-36; discussion S36-8.

12. Szabo N, Kincses ZT, Toldi J, Vecsei L. Altered tryptophan metabolism in Parkinson's disease: a possible novel therapeutic approach. J Neurol Sci 2011 Nov 15;310(1-2):256-60.

13. Zadori D, Klivenyi P, Toldi J, Fulop F, Vecsei L. Kynurenines in Parkinson's disease: therapeutic perspectives. J Neural Transm 2012 Feb;119(2):275-83.

14. Obal I, Majlath Z, Toldi J, Vecsei L. Mental disturbances in Parkinson's disease and related disorders: the role of excitotoxins. J Parkinsons Dis 2014;4(2):139-50.

15. Dezsi L, Vecsei L. Clinical implications of irregular ADMET properties with levodopa and other antiparkinson's drugs. Expert Opin Drug Metab Toxicol 2014 Mar;10(3):409-24.

16. Calabresi P, Ghiglieri V, Mazzocchetti P, Corbelli I, Picconi B. Levodopa-induced plasticity: a double-edged sword in Parkinson's disease? Philos Trans R Soc Lond B Biol Sci 2015 Jul 5;370(1672).

17. Allen PJ, Feigin A. Gene-based therapies in Parkinson's disease. Neurotherapeutics 2014 Jan;11(1):60-7.

18. Klivenyi P, Vecsei L. Novel therapeutic strategies in Parkinson's disease. Eur J Clin Pharmacol 2010 Feb;66(2):119-25.

19. Dezsi L, Vecsei L. Safinamide for the treatment of Parkinson's disease. Expert Opin Investig Drugs 2014 May;23(5):729-42. 
20. Akerud P, Canals JM, Snyder EY, Arenas E. Neuroprotection through delivery of glial cell linederived neurotrophic factor by neural stem cells in a mouse model of Parkinson's disease. J Neurosci 2001 Oct 15;21(20):8108-18.

21. Cunningham LA, Su C. Astrocyte delivery of glial cell line-derived neurotrophic factor in a mouse model of Parkinson's disease. Exp Neurol 2002 Apr;174(2):230-42.

22. Park KW, Eglitis MA, Mouradian MM. Protection of nigral neurons by GDNF-engineered marrow cell transplantation. Neurosci Res 2001 Aug;40(4):315-23.

23. Manfredsson FP, Bloom DC, Mandel RJ. Regulated protein expression for in vivo gene therapy for neurological disorders: progress, strategies, and issues. Neurobiol Dis 2012 Nov;48(2):212-21.

24. Kaplitt MG, Feigin A, Tang C, Fitzsimons HL, Mattis P, Lawlor PA, et al. Safety and tolerability of gene therapy with an adeno-associated virus (AAV) borne GAD gene for Parkinson's disease: an open label, phase I trial. Lancet 2007 Jun 23;369(9579):2097-105.

25. Araki K, Takino T, Ida S, Kuriyama K. Alteration of amino acids in cerebrospinal fluid from patients with Parkinson's disease and spinocerebellar degeneration. Acta Neurol Scand 1986 Feb;73(2):105-10.

26. Levy R, Lang AE, Dostrovsky JO, Pahapill P, Romas J, Saint-Cyr J, et al. Lidocaine and muscimol microinjections in subthalamic nucleus reverse Parkinsonian symptoms. Brain 2001 Oct;124(Pt 10):2105-18.

27. Obeso JA, Rodriguez-Oroz MC, Rodriguez M, Macias R, Alvarez L, Guridi J, et al. Pathophysiologic basis of surgery for Parkinson's disease. Neurology 2000;55(12 Suppl 6):S7-12.

28. Erlander MG, Tillakaratne NJ, Feldblum S, Patel N, Tobin AJ. Two genes encode distinct glutamate decarboxylases. Neuron 1991 Jul;7(1):91-100.

29. Wichmann T, DeLong MR. Pathophysiology of Parkinson's disease: the MPTP primate model of the human disorder. Ann N Y Acad Sci 2003 Jun;991:199-213.

30. Stayte S, Vissel B. Advances in non-dopaminergic treatments for Parkinson's disease. Front Neurosci 2014;8:113.

31. Emborg ME, Carbon M, Holden JE, During MJ, Ma Y, Tang C, et al. Subthalamic glutamic acid decarboxylase gene therapy: changes in motor function and cortical metabolism. J Cereb Blood Flow Metab 2007 Mar;27(3):501-9.

32. Feigin A, Kaplitt MG, Tang C, Lin T, Mattis P, Dhawan V, et al. Modulation of metabolic brain networks after subthalamic gene therapy for Parkinson's disease. Proc Natl Acad Sci U S A 2007 Dec 4;104(49):19559-64.

33. LeWitt PA, Rezai AR, Leehey MA, Ojemann SG, Flaherty AW, Eskandar EN, et al. AAV2-GAD gene therapy for advanced Parkinson's disease: a double-blind, sham-surgery controlled, randomised trial. Lancet Neurol 2011 Apr;10(4):309-19.

34. Ko JH, Feigin A, Mattis PJ, Tang CC, Ma Y, Dhawan V, et al. Network modulation following sham surgery in Parkinson's disease. J Clin Invest 2014 Aug;124(8):3656-66.

35. Grondin R, Cass WA, Zhang Z, Stanford JA, Gash DM, Gerhardt GA. Glial cell line-derived neurotrophic factor increases stimulus-evoked dopamine release and motor speed in aged rhesus monkeys. J Neurosci 2003 Mar 1;23(5):1974-80.

36. Ai Y, Markesbery W, Zhang Z, Grondin R, Elseberry D, Gerhardt GA, et al. Intraputamenal infusion of GDNF in aged rhesus monkeys: distribution and dopaminergic effects. J Comp Neurol 2003 Jun 23;461(2):250-61.

37. Grondin R, Zhang Z, Yi A, Cass WA, Maswood N, Andersen AH, et al. Chronic, controlled GDNF infusion promotes structural and functional recovery in advanced parkinsonian monkeys. Brain 2002 Oct;125(Pt 10):2191-201.

38. Rosenblad C, Kirik D, Bjorklund A. Sequential administration of GDNF into the substantia nigra and striatum promotes dopamine neuron survival and axonal sprouting but not striatal reinnervation or functional recovery in the partial 6-OHDA lesion model. Exp Neurol 2000 Feb;161(2):503-16.

39. Palfi S, Leventhal L, Chu Y, Ma SY, Emborg M, Bakay R, et al. Lentivirally delivered glial cell linederived neurotrophic factor increases the number of striatal dopaminergic neurons in primate models of nigrostriatal degeneration. J Neurosci 2002 Jun 15;22(12):4942-54. 
40. Eslamboli A, Cummings RM, Ridley RM, Baker HF, Muzyczka N, Burger C, et al. Recombinant adeno-associated viral vector ( $\mathrm{rAAV}$ ) delivery of GDNF provides protection against 6-OHDA lesion in the common marmoset monkey (Callithrix jacchus). Exp Neurol 2003 Nov;184(1):536-48.

41. Nutt JG, Burchiel KJ, Comella CL, Jankovic J, Lang AE, Laws ER, Jr., et al. Randomized, doubleblind trial of glial cell line-derived neurotrophic factor (GDNF) in PD. Neurology 2003 Jan 14;60(1):6973.

42. Gill SS, Patel NK, Hotton GR, O'Sullivan K, McCarter R, Bunnage M, et al. Direct brain infusion of glial cell line-derived neurotrophic factor in Parkinson disease. Nat Med 2003 May;9(5):589-95.

43. Bartus RT, Weinberg MS, Samulski RJ. Parkinson's disease gene therapy: success by design meets failure by efficacy. Mol Ther 2014 Mar;22(3):487-97.

44. Witt J, Marks WJ, Jr. An update on gene therapy in Parkinson's disease. Curr Neurol Neurosci Rep 2011 Aug;11(4):362-70.

45. Marks WJ, Jr., Ostrem JL, Verhagen L, Starr PA, Larson PS, Bakay RA, et al. Safety and tolerability of intraputaminal delivery of CERE-120 (adeno-associated virus serotype 2-neurturin) to patients with idiopathic Parkinson's disease: an open-label, phase I trial. Lancet Neurol 2008 May;7(5):400-8.

46. Marks WJ, Jr., Bartus RT, Siffert J, Davis CS, Lozano A, Boulis N, et al. Gene delivery of AAV2neurturin for Parkinson's disease: a double-blind, randomised, controlled trial. Lancet Neurol 2010 Dec;9(12):1164-72.

47. Bartus RT, Baumann TL, Siffert J, Herzog CD, Alterman R, Boulis N, et al. Safety/feasibility of targeting the substantia nigra with AAV2-neurturin in Parkinson patients. Neurology 2013 Apr 30;80(18):1698-701.

48. Warren Olanow C, Bartus RT, Baumann TL, Factor S, Boulis N, Stacy M, et al. Gene delivery of neurturin to putamen and substantia nigra in Parkinson disease: A double-blind, randomized, controlled trial. Ann Neurol 2015 Aug;78(2):248-57.

49. Bartus RT, Kordower JH, Johnson EM, Jr., Brown L, Kruegel BR, Chu Y, et al. Post-mortem assessment of the short and long-term effects of the trophic factor neurturin in patients with alphasynucleinopathies. Neurobiol Dis 2015 Jun;78:162-71.

50. Kordower JH, Bjorklund A. Trophic factor gene therapy for Parkinson's disease. Mov Disord 2013 Jan;28(1):96-109.

51. Bankiewicz KS, Eberling JL, Kohutnicka M, Jagust W, Pivirotto P, Bringas J, et al. Convectionenhanced delivery of AAV vector in parkinsonian monkeys; in vivo detection of gene expression and restoration of dopaminergic function using pro-drug approach. Exp Neurol 2000 Jul;164(1):2-14.

52. Bankiewicz KS, Forsayeth J, Eberling JL, Sanchez-Pernaute R, Pivirotto P, Bringas J, et al. Longterm clinical improvement in MPTP-lesioned primates after gene therapy with AAV-hAADC. Mol Ther 2006 Oct;14(4):564-70.

53. Eberling JL, Jagust WJ, Christine CW, Starr P, Larson P, Bankiewicz KS, et al. Results from a phase I safety trial of hAADC gene therapy for Parkinson disease. Neurology 2008 May 20;70(21):1980-3.

54. Christine CW, Starr PA, Larson PS, Eberling JL, Jagust WJ, Hawkins RA, et al. Safety and tolerability of putaminal AADC gene therapy for Parkinson disease. Neurology 2009 Nov $17 ; 73(20): 1662-9$.

55. Valles F, Fiandaca MS, Eberling JL, Starr PA, Larson PS, Christine CW, et al. Qualitative imaging of adeno-associated virus serotype 2-human aromatic L-amino acid decarboxylase gene therapy in a phase I study for the treatment of Parkinson disease. Neurosurgery 2010 Nov;67(5):1377-85.

56. Palfi S, Gurruchaga JM, Ralph GS, Lepetit H, Lavisse S, Buttery PC, et al. Long-term safety and tolerability of ProSavin, a lentiviral vector-based gene therapy for Parkinson's disease: a dose escalation, open-label, phase 1/2 trial. Lancet 2014 Mar 29;383(9923):1138-46.

57. Jarraya B, Boulet S, Ralph GS, Jan C, Bonvento G, Azzouz M, et al. Dopamine gene therapy for Parkinson's disease in a nonhuman primate without associated dyskinesia. Sci Transl Med 2009 Oct 14;1(2):2ra4. 
58. Majlath Z, Vecsei L. NMDA antagonists as Parkinson's disease therapy: disseminating the evidence. Neurodegener Dis Manag 2014;4(1):23-30.

59. Gregoire L, Morin N, Ouattara B, Gasparini F, Bilbe G, Johns D, et al. The acute antiparkinsonian and antidyskinetic effect of AFQ056, a novel metabotropic glutamate receptor type 5 antagonist, in L-Dopa-treated parkinsonian monkeys. Parkinsonism Relat Disord 2011 May;17(4):270-6.

60. Berg D, Godau J, Trenkwalder C, Eggert K, Csoti I, Storch A, et al. AFQ056 treatment of levodopa-induced dyskinesias: results of 2 randomized controlled trials. Mov Disord 2011 Jun;26(7):1243-50.

61. Petrov D, Pedros I, de Lemos ML, Pallas M, Canudas AM, Lazarowski A, et al. Mavoglurant as a treatment for Parkinson's disease. Expert Opin Investig Drugs 2014 Aug;23(8):1165-79.

62. Rascol O, Fox S, Gasparini F, Kenney C, Di Paolo T, Gomez-Mancilla B. Use of metabotropic glutamate 5-receptor antagonists for treatment of levodopa-induced dyskinesias. Parkinsonism Relat Disord 2014 Sep;20(9):947-56.

63. Dickerson JW, Conn PJ. Therapeutic potential of targeting metabotropic glutamate receptors for Parkinson's disease. Neurodegener Dis Manag 2012 Apr 1;2(2):221-32.

64. Chan CS, Guzman JN, Ilijic E, Mercer JN, Rick C, Tkatch T, et al. 'Rejuvenation' protects neurons in mouse models of Parkinson's disease. Nature 2007 Jun 28;447(7148):1081-6.

65. Ilijic E, Guzman JN, Surmeier DJ. The L-type channel antagonist isradipine is neuroprotective in a mouse model of Parkinson's disease. Neurobiol Dis 2011 Aug;43(2):364-71.

66. Becker C, Jick SS, Meier CR. Use of antihypertensives and the risk of Parkinson disease. Neurology 2008 Apr 15;70(16 Pt 2):1438-44.

67. Ritz B, Rhodes SL, Qian L, Schernhammer E, Olsen JH, Friis S. L-type calcium channel blockers and Parkinson disease in Denmark. Ann Neurol 2010 May;67(5):600-6.

68. Dragicevic E, Poetschke C, Duda J, Schlaudraff F, Lammel S, Schiemann J, et al. Cav1.3 channels control D2-autoreceptor responses via NCS-1 in substantia nigra dopamine neurons. Brain 2014 Aug;137(Pt 8):2287-302.

69. Branch SY, Sharma R, Beckstead MJ. Aging decreases L-type calcium channel currents and pacemaker firing fidelity in substantia nigra dopamine neurons. J Neurosci 2014 Jul 9;34(28):9310-8.

70. Simuni T, Borushko E, Avram MJ, Miskevics S, Martel A, Zadikoff C, et al. Tolerability of isradipine in early Parkinson's disease: a pilot dose escalation study. Mov Disord 2010 Dec 15;25(16):2863-6.

71. Group PS. Phase II safety, tolerability, and dose selection study of isradipine as a potential disease-modifying intervention in early Parkinson's disease (STEADY-PD). Mov Disord 2013 Nov;28(13):1823-31.

72. Szabo N, Kincses ZT, Vecsei L. Novel therapy in Parkinson's disease: adenosine A(2A) receptor antagonists. Expert Opin Drug Metab Toxicol 2011 Apr;7(4):441-55.

73. Bara-Jimenez W, Sherzai A, Dimitrova T, Favit A, Bibbiani F, Gillespie M, et al. Adenosine A(2A) receptor antagonist treatment of Parkinson's disease. Neurology 2003 Aug 12;61(3):293-6.

74. Fernandez HH, Greeley DR, Zweig RM, Wojcieszek J, Mori A, Sussman NM. Istradefylline as monotherapy for Parkinson disease: results of the 6002-US-051 trial. Parkinsonism Relat Disord 2010 Jan;16(1):16-20.

75. Hauser RA, Hubble JP, Truong DD. Randomized trial of the adenosine $A(2 A)$ receptor antagonist istradefylline in advanced PD. Neurology 2003 Aug 12;61(3):297-303.

76. Mizuno Y, Hasegawa K, Kondo T, Kuno S, Yamamoto M. Clinical efficacy of istradefylline (KW6002) in Parkinson's disease: a randomized, controlled study. Mov Disord 2010 Jul 30;25(10):1437-43.

77. Chen W, Wang $H$, Wei $H$, Gu S. Istradefylline, an adenosine $A(2) A$ receptor antagonist, for patients with Parkinson's Disease: a meta-analysis. J Neurol Sci 2013 Jan 15;324(1-2):21-8.

78. LeWitt PA, Guttman M, Tetrud JW, Tuite PJ, Mori A, Chaikin P, et al. Adenosine A2A receptor antagonist istradefylline (KW-6002) reduces "off" time in Parkinson's disease: a double-blind, randomized, multicenter clinical trial (6002-US-005). Ann Neurol 2008 Mar;63(3):295-302. 
79. Stacy M, Silver D, Mendis T, Sutton J, Mori A, Chaikin P, et al. A 12-week, placebo-controlled study (6002-US-006) of istradefylline in Parkinson disease. Neurology 2008 Jun 3;70(23):2233-40.

80. Black KJ CM, Dickerson W, Creech ML, Koller JM,Chung S, Bandak SI. A randomized, doubleblind, placebo-controlled cross-over trial of the adenosine 2a antagonist SYN115 in Parkinson disease. . Neurology 2010;74(Suppl.2.):A317.

81. Hauser RA, Olanow CW, Kieburtz KD, Pourcher E, Docu-Axelerad A, Lew M, et al. Tozadenant (SYN115) in patients with Parkinson's disease who have motor fluctuations on levodopa: a phase $2 b$, double-blind, randomised trial. Lancet Neurol 2014 Aug;13(8):767-76.

82. Pinna A. Adenosine A2A receptor antagonists in Parkinson's disease: progress in clinical trials from the newly approved istradefylline to drugs in early development and those already discontinued. CNS Drugs 2014 May;28(5):455-74.

83. Feng LR, Maguire-Zeiss KA. Gene therapy in Parkinson's disease: rationale and current status. CNS Drugs 2010 Mar;24(3):177-92.

84. $\mathrm{Xu} \mathrm{H}, \mathrm{Li} \mathrm{Z}, \mathrm{Si}$ J. Nanocarriers in gene therapy: a review. J Biomed Nanotechnol 2014 Dec;10(12):3483-507. 
1. Table Summary of clinical gene therapy trials in Parkinson's disease

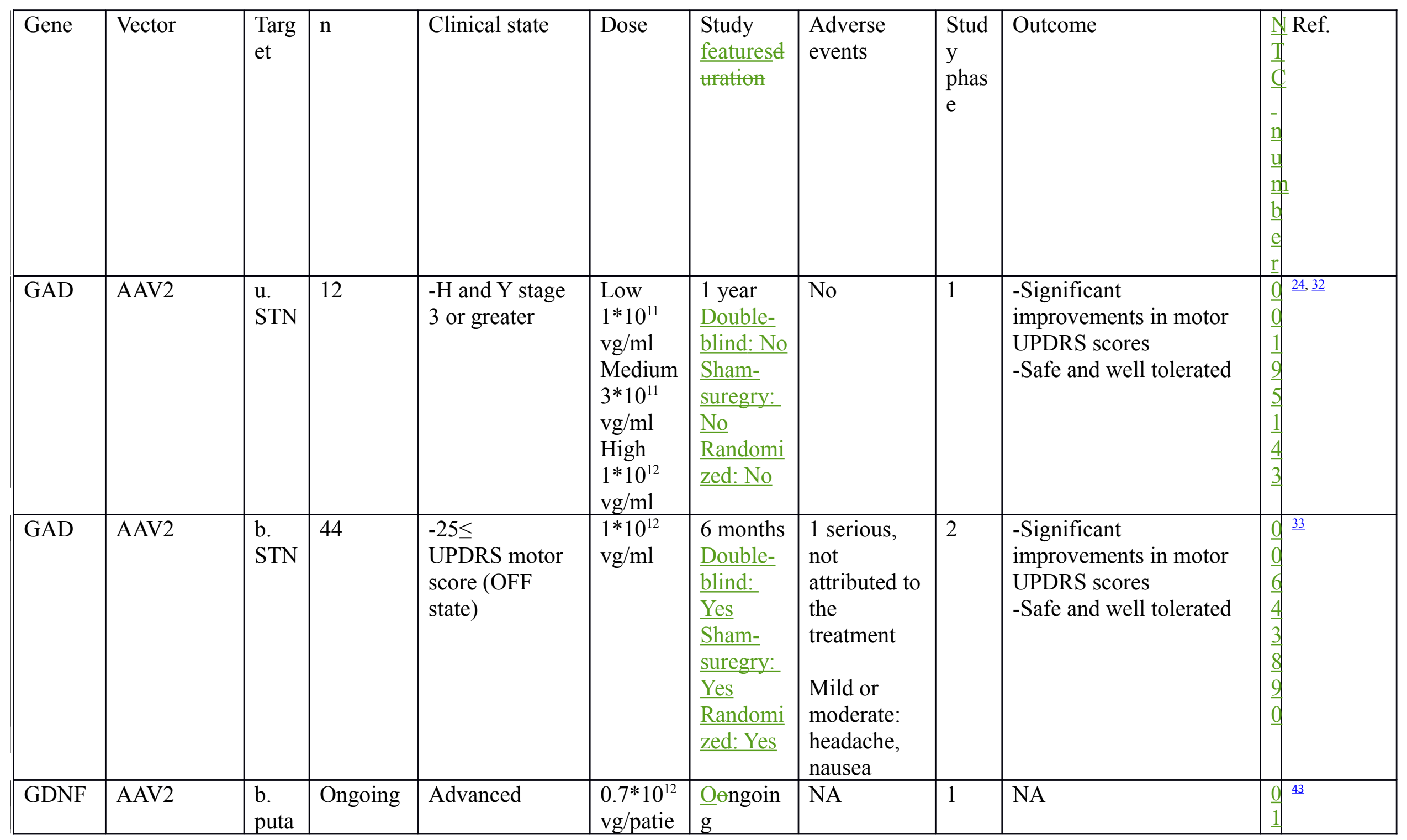




\begin{tabular}{|c|c|c|c|c|c|c|c|c|c|c|c|}
\hline & & men & & & $\mathrm{nt}$ & $\begin{array}{l}\text { Double- } \\
\text { blind: No } \\
\text { Sham- } \\
\text { suregry: } \\
\frac{\text { No }}{\text { Randomi }} \\
\text { zed: No }\end{array}$ & & & & \begin{tabular}{l|} 
\\
$\frac{6}{2}$ \\
$\frac{1}{5}$ \\
$\frac{5}{8}$ \\
1
\end{tabular} & \\
\hline $\begin{array}{l}\text { Neurtu } \\
\text { rin } \\
(\text { CERE } \\
-120)\end{array}$ & AAV2 & $\begin{array}{l}\text { b. } \\
\text { puta } \\
\text { men }\end{array}$ & 12 & $\begin{array}{l}\text {-Moderate to } \\
\text { severe, } \\
-\mathrm{H} \text { and Y stage } \\
3 \text { or } 4, \\
-30 \leq \\
\text { UPDRS motor } \\
\text { score (OFF } \\
\text { state) }\end{array}$ & $\begin{array}{l}\text { Low } \\
1.3^{*} 10^{11} \\
\text { vg/patie } \\
\text { nt } \\
\text { High } \\
5.4^{*} 10^{11} \\
\text { vg/patie } \\
\text { nt }\end{array}$ & $\begin{array}{l}1 \text { year } \\
\text { Double- } \\
\text { blind: No } \\
\underline{\text { Sham- }} \\
\underline{\text { suregry: }} \\
\underline{\text { No }} \\
\underline{\text { Randomi }} \\
\underline{\text { zed: No }}\end{array}$ & No & 1 & $\begin{array}{l}\text {-Significant } \\
\text { improvements in motor } \\
\text { UPDRS scores } \\
\text {-Safe and well tolerated }\end{array}$ & $\begin{array}{l}0 \\
0 \\
0 \\
\frac{1}{5} \\
\frac{5}{2} \\
\frac{2}{3} \\
\frac{8}{5} \\
\frac{5}{2} \\
\end{array}$ & 45 \\
\hline $\begin{array}{l}\text { Neurtu } \\
\text { rin } \\
(\text { CERE } \\
-120)\end{array}$ & AAV2 & $\begin{array}{l}\mathrm{b} . \\
\text { puta } \\
\text { men }\end{array}$ & 58 & $\begin{array}{l}\text {-Advanced PD, } \\
-30 \leq \\
\text { UPDRS motor } \\
\text { score (OFF } \\
\text { state) }\end{array}$ & $\begin{array}{l}5.4^{*} 10^{11} \\
\mathrm{vg} / \text { patie } \\
\mathrm{nt}\end{array}$ & $\begin{array}{l}1 \text { year } \\
\text { Double- } \\
\text { blind: } \\
\text { Yes } \\
\text { Sham- } \\
\text { suregry: } \\
\underline{\text { Yes }} \\
\text { Randomi } \\
\text { zed: Yes }\end{array}$ & $\begin{array}{l}\text { Serious } \\
\text { adverse } \\
\text { events: } \\
13 \text { of } 38 \text { in } \\
\text { the } \\
\text { neurturin } \\
\text { group ( } 3 \\
\text { tumors) } \\
4 \text { of } 20 \text { in } \\
\text { the sham } \\
\text { surgery } \\
\text { controls ( } 2 \\
\text { tumors) }\end{array}$ & 2 & $\begin{array}{l}\text {-No significant } \\
\text { improvements in motor } \\
\text { UPDRS scores }\end{array}$ & $\begin{array}{l}0 \\
0 \\
\text { d } \\
\text { d } \\
\text { d } \\
\text { d }\end{array}$ & 46 \\
\hline $\begin{array}{l}\text { Neurtu } \\
\text { rin } \\
\text { (CERE }\end{array}$ & AAV2 & $\begin{array}{l}\text { b. } \\
\text { puta } \\
\text { men }\end{array}$ & 6 & $\begin{array}{l}\text {-Moderately } \\
\text { advanced, } \\
\text { - H and Y stage }\end{array}$ & $\begin{array}{l}\text { Low } \\
4.0 * 10^{11} \\
\text { vg/patie }\end{array}$ & $\begin{array}{l}2 \text { years } \\
\text { Double- } \\
\text { blind: No } \\
\end{array}$ & No & 1 & -Safe and well tolerated & $\underline{0}$ & 47 \\
\hline
\end{tabular}




\begin{tabular}{|c|c|c|c|c|c|c|c|c|c|c|c|}
\hline-120$)$ & & STN & & $\begin{array}{l}2 \text { or } 3 \\
-34 \leq \\
\text { UPDRS motor } \\
\text { score (OFF } \\
\text { state) }\end{array}$ & $\begin{array}{l}\text { nt } \\
\text { High } \\
5.4^{*} 10^{11} \\
\text { vg/patie } \\
\text { nt }\end{array}$ & $\begin{array}{l}\text { Sham- } \\
\text { Suregry: } \\
\text { No } \\
\text { Randomi } \\
\text { zed: No }\end{array}$ & & & & $\begin{array}{l}8 \\
5 \\
5 \\
\frac{5}{2} \\
\frac{1}{2}\end{array}$ & \\
\hline $\begin{array}{l}\frac{\text { Neurtu }}{\text { rin }} \\
\text { (CERE } \\
-120)\end{array}$ & AAV2 & $\begin{array}{l}\frac{\text { b. }}{\text { puta }} \\
\underline{\text { men }} \\
\underline{\text { STN }}\end{array}$ & $\underline{51 / 47}$ & $\begin{array}{l}\text {-good-response } \\
\text { to L-Dopa } \\
\text {-stable doses of } \\
\text { antiparkinsoina } \\
\text { drugs for at } \\
\text { least 6 weeks } \\
\underline{\text {-mean H and Y }} \\
\underline{\text { stage } 2.5(0.51)} \\
\frac{\text {-the mean value }}{\text { of UPDRS }} \\
\frac{\text { motor score }}{\text { OFF state) }} \\
\frac{\text { were bigger }}{\text { than } 35 \text { in both }} \\
\text { groups }\end{array}$ & $\begin{array}{l}\frac{\text { Substan }}{\text { tia nigra }} \\
\underline{2.0^{*} * 10^{11}} \\
\text { vg/patie } \\
\underline{\mathrm{nt}} \\
\underline{\text { Putame }} \\
\underline{\mathrm{n}} \\
\underline{1.0 * 10^{12}} \\
\underline{\mathrm{vg} / \text { patie }^{2}} \\
\underline{\mathrm{nt}}\end{array}$ & $\begin{array}{l}\frac{2 \text { years }}{\text { Double- }} \\
\frac{\text { blind: }}{\text { Yes }} \\
\text { Sham- } \\
\text { suregry: } \\
\underline{\text { Yes }} \\
\text { Randomi } \\
\text { zed: Yes }\end{array}$ & $\begin{array}{l}\text { No } \\
\text { clinically } \\
\underline{\text { adverse }} \\
\underline{\text { events }} \\
\underline{\text { occured }}\end{array}$ & $\underline{1}$ & $\underline{\text { Safe and well tolerated }}$ & $\begin{array}{l}0 \\
\frac{0}{9} \\
\frac{9}{5} \\
\frac{1}{5}\end{array}$ & 48 \\
\hline AADC & AAV2 & $\begin{array}{l}\mathrm{b} . \\
\text { puta } \\
\text { men }\end{array}$ & 5 & $\begin{array}{l}\text {-Moderate to } \\
\text { advanced }\end{array}$ & Low & $\begin{array}{l}6 \text { months } \\
\text { Double- } \\
\text { blind: No } \\
\underline{\text { Sham- }} \\
\underline{\text { suregry: }} \\
\underline{\text { No }} \\
\text { Randomi } \\
\underline{\text { zed: No }}\end{array}$ & No & 1 & $\begin{array}{l}\text { - Safe and well tolerated } \\
\text { - Modest improvement } \\
\text { (interpretation dificulties: } \\
\text { no control, non-blinded } \\
\text { analysis) } \\
\text {-PET: evidence of } \\
\text { sustained gene } \\
\text { expression }\end{array}$ & & $\underline{53}$ \\
\hline AADC & AAV2 & $\begin{array}{l}\text { b. } \\
\text { puta } \\
\text { men }\end{array}$ & 10 & $\begin{array}{l}\text {-Moderately } \\
\text { advanced }\end{array}$ & $\begin{array}{l}\text { Low } \\
9 * 10^{10} \\
\text { vg/patie }\end{array}$ & $\begin{array}{l}6 \text { months } \\
\text { Double- } \\
\text { blind: No }\end{array}$ & $\begin{array}{l}\text { No serious } \\
1\end{array}$ & 1 & $\begin{array}{l}\text {-Safe and well tolerated } \\
\text {-The necessary amount } \\
\text { of dopaminergic }\end{array}$ & $\underline{c}$ & 54 \\
\hline
\end{tabular}




\begin{tabular}{|c|c|c|c|c|c|c|c|c|c|c|}
\hline & & & & & $\begin{array}{l}\text { nt } \\
\text { High } \\
3 * 10^{11} \\
\text { vg/patie } \\
\text { nt }\end{array}$ & $\begin{array}{l}\text { Sham- } \\
\text { suregry: } \\
\text { No } \\
\text { Randomi } \\
\text { zed: No }\end{array}$ & $\begin{array}{l}\text { symptomati } \\
\mathrm{c} \text { and } 2 \\
\text { asymptomat } \\
\text { ic } \\
\text { intracranial } \\
\text { hemorrhage } \\
\text { s, headache }\end{array}$ & & $\begin{array}{l}\text { medication was reduced } \\
\text { in } 8 \text { patients } \\
\text {-FMT PET: } 30 \% \text { increase } \\
\text { of putaminal uptake in } \\
\text { the low-dose cohort, } 75 \% \\
\text { increase in the high-dose } \\
\text { cohort } \\
\text {-Total and motor rating } \\
\text { scales improved in both } \\
\text { cohorts } \\
\text {-Motor diaries also } \\
\text { showed increased ON- } \\
\text { time and reduced OFF- } \\
\text { time without increased } \\
\text { ON-time dyskinesia } \\
\end{array}$ & $\begin{array}{l}2 \\
9 \\
\frac{1}{3} \\
3 \\
\\
\end{array}$ \\
\hline $\begin{array}{l}\text { ProSav } \\
\text { in } \underline{\mathbb{}} \\
\text { (Lenti- } \\
\text { TH- } \\
\text { AADC } \\
- \text { GCH) }\end{array}$ & lenti-virus & $\begin{array}{l}\mathrm{b} . \\
\text { puta } \\
\text { men }\end{array}$ & 15 & $\begin{array}{l}-\mathrm{H} \text { and Y stage } \\
3 \text { or } 4 \text { in (OFF } \\
\text { state) } \\
\text {-UPDRS (OFF } \\
\text { medication) } \\
\text { between } 20 \text { and } \\
60 ;\end{array}$ & $\begin{array}{l}\text { Low } \\
1.9^{*} 10^{7} \\
\text { TU } \\
\text { Medium } \\
4.0^{*} 10^{7} \\
\text { TU } \\
\text { High } \\
1 * 10^{8} \\
\text { TU }\end{array}$ & $\begin{array}{l}1 \text { year, } \\
\text { prolonge } \\
\text { d for } 10 \\
\text { years } \\
\text { Double- } \\
\text { blind: No } \\
\text { Sham- } \\
\text { suregry: } \\
\text { No } \\
\text { Randomi } \\
\text { zed: No }\end{array}$ & $\begin{array}{l}\text { No serious } \\
51 \text { mild, } \\
\text { three } \\
\text { moderate }\end{array}$ & $1 / 2$ & $\begin{array}{l}\text {-Safe and well tolerated } \\
\text {-Significant improvement } \\
\text { in mean UPDRS part III } \\
\text { motor scores OFF } \\
\text { medication } \\
\text {-Improvement in motor } \\
\text { behavior was observed in } \\
\text { all patients. }\end{array}$ & 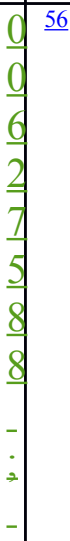 \\
\hline
\end{tabular}




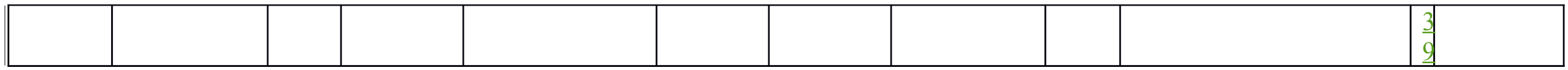

u.:unilateral, b.: bilateral, $\mathrm{H}$ and Y: Hoehn and Yahr stage, TU: transducing units. 


\section{Figure legends}

Figure 1. Gene therapy approaches.

I. Ex vivo gene therapy: In case of this approach, patients receive genetically modified cells that express a desired protein or proteins. The genetic modifications of the patient's target cells are performed outside the body, in a cell culture.

1.:Copies of the therapeutic gene(s) integrate into the viral DNA. 2.: The target cells of the patient are removed and grown in a cell culture. 3.: The cultured cells are transfected with the genetically modified virus. 4.: These transfected cells are reintroduced into the patient's body, where they express the necessary protein(s).

II. In vivo gene therapy: In this case, the genetic information is directly inserted into the patient's own cells.

1.: The therapeutic gene(s) can be inserted into viral DNA, coated in a liposome or created in form of a plasmid DNA. 2.:The genetically modified DNA is transferred by cell-specific direct tissue injection (or in case of a plasmid vector by dermal vaccination). 3.: Inside the patient's body, the inserted DNA is incorporated into the cells of the targeted tissue and starts to produce the encoded $\operatorname{protein}(\mathrm{s})$.

Figure 2. Adenosin $\mathrm{A}_{2 \mathrm{~A}}$ antagonists

This figure displays the chemical structures of adenosin $\mathrm{A}_{2 \mathrm{~A}}$ antagonists. 